\title{
電子部品と実装技術における現状と今後の展望
}

\section{Current Status and Future Perspective of Electronics Components \& Electronics Packaging Technologies}

\author{
電子部品・実装技術委員会
}

\section{1.はじめに}

電子部品・実装技術委員会には, 先進実装・電子部品研 究会とプリンタブルデバイス実装研究会の 2 つの研究会を 金下に擁しており，実装技術に関する最先端技術の研究を 牽引されているアカデミアの先生方, 電子部品, プリント 配線板, パワーエレクトロニクス, カーエレクトロニク ス, 材料, 装置に関連する企業の研究者や技術者, JEITA やJPCA に携わる委員などで構成されている。小型・高密 度・高性能化が進む電子機器の実装技術のあるべき姿につ いて, 外部の専門家の協力も得ながら定期的に公開研究会 を開催して情報発信を行っている。また専門分野が異なっ た委員が集い，新しい材料や技術への探索も持続的に行っ ている。

本稿では，国内外で競争が激化する電子機器業界におい て，各分野を担当する委員から現状および今後の展望につ いて紹介する。

\section{2. プリント配線板}

\section{1 プリント配線板市場動向}

世界のプリント配線板市場はこの数年間堅調な成長を示 しており，2018 年には年間で約 700 億ドルの市場が見込ま れている（図 1)。その成長を牽引しているのがスマート

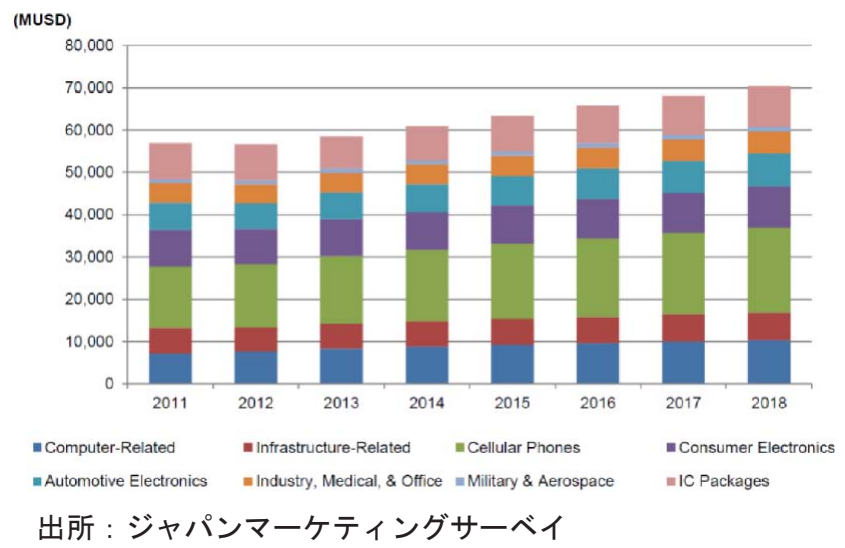

図 1. 分野別の世界プリント配線板市場規模予測
フォン, コンピュータ関連製品, ICパッケージ, 車載部品 である。自動車の電動化や電子化の進展, 新生の中国ス マートフォンメーカの躍進などにより, 製品の生産台数が 増え，それに使用されるプリント配線板の市場も増加傾向 である ${ }^{1)}$

\section{2 スマートフォン向けプリント配線板技術動向}

スマートフォンのメインボードは, バッテリーの大容量 化により年々小型化の一途をたどっている。加えてメイン CPU の I/O の増加や狭ピッチ化により, デザインルールの 高密度化や配線層の層数増加も年々進んでいる ${ }^{2)}$ (図 2)。

これまでは回路形成にサブトラクティブ法が用いられ， 電解銅めつきの薄膜化やエッチング技術の向上により細線 形成を行い，デザインルールの高密度化に対応してきた。 そして，いよいよサブトラクティブ法では対応できないデ ザインルールが要求され始めてきた。これまでモジュール 基板やパッケージサブストレートの回路形成に用いられて きたセミアディティブ法が，今後メインボードにも応用さ れる(図 3 )。

\section{3 セミアディティブ法}

この変化はプリント配線板製造分野に大きな影響を与え ることになる。メインボードの供給は，従来の製造メーカ

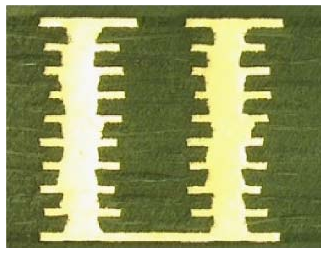

図 2.メインボード

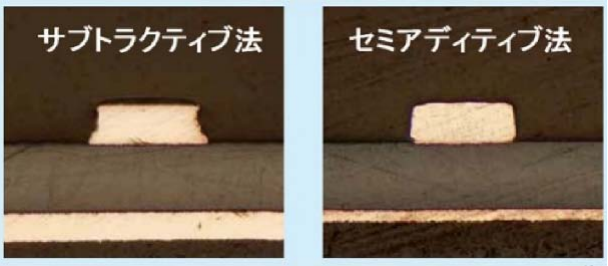

図 3. 回路断面形状比較 
からパッケージサブストレート製造メーカへとシフトす る。また, 生産能力増強が必要になるため, 活発な設備投 資が行われる。

プリント配線板製造技術にも大きな影響を与える。サブ トラクティブ法ではドライフィルム形成後にエッチングを 行うが, セミアデイティブ法では電解銅めっきを行う。こ れにより製造ラインの構成を変更することになり, 用途が 異なることからドライフィルムの変更, それを感光させる ための露光装置も変更が必要となる。求められる性能が異 なるため, 電解銅めっきの薬液も組成の変更が必要とな る。今, メインボードを取り巻く環境は大きな変革期を迎 えている。

$$
\text { 文責・戸田光昭 /メイコー }
$$

\section{3. パワーエレクトロニクス}

パワーエレクトロニクス（以下，PE）に関連する実装技 術について述べる。本特集号の, パワーエレクトロニクス 研究会にて, デバイスやモジュールについての動向や状況 については解説されているため, 実装を切り口にPEA (Power Electronics Assembly) について注目して話題とする。

これまでも多くのPEについて語られているが, 従来の 産業機器, 鉄道車両などのモータコントロール分野から, 近年ではハイブリッドカーや電気自動車での $\mathrm{CO}_{2}$ 削減, ま た太陽光, 風力発電などの新エネルギの電力変換分野な ど，新たな分野における適用が進んでいる。某社のアジア スマートグリット構想など, 電力変換技術が躍進的に伸長 する潜在的な要素をもっている。

このような方向性の中で, パワーエレクトロニクス実装 技術に対しては,

(1)システム化・小型化

（回路技術，センサー搭載技術）

(2)高耐熱・高耐圧化

（材料技術，接合技術，絶縁技術，封止技術）

(3)大電流化

（低インダクタンス技術，放熱技術，冷却技術） の技術革新が求められる予測がパワーエレクトロニクス研 究会から報告されており, PCBA (Print Circuit Board Assembly)のPEA についても注目がされている。

昨今の学会や研究会, シンポジウムなどでも, PE 技術を 題目とした講演が数多くなされている ${ }^{3)}$ 。

\subsection{PEA 実装技術}

2016 年より数年は, $\mathrm{SiC}$ などの次世代素子を用いた製品 の $\mathrm{Si} へ$ の置き換えは, 技術面, コスト面での課題が大き く，しばらく先のことになりそうなことが，だんだんと明 らかになり，Siとダイオードだけ $\mathrm{SiC}$ を使用したハイブリッ ドパワーモジュールの上市などが検討され，車両分野など が，車載（自動車関連の製品）よりも先に製品適用される のではないかと考えられているようだ。これは車両製品で
表 1.はんだ使用温度の高温化に伴う $\mathrm{T} / \mathrm{Tm}$ 值 (SnAg 系鉛フリーはんだと鉄の比較)

\begin{tabular}{c|c|c}
\hline \multirow{2}{*}{$\mathrm{T} / \mathrm{Tm}$} & \multicolumn{2}{|c}{ 製品要求温度 $($ 鉄は比較材 $)$} \\
\cline { 2 - 3 } & はんだ $\left({ }^{\circ} \mathrm{C}\right)$ & 鉄 $\left({ }^{\circ} \mathrm{C}\right)$ \\
\hline 0.67 & 60 & 950 \\
\hline 0.76 & 100 & 1,100 \\
\hline 0.81 & 125 & 1,190 \\
\hline 0.86 & 150 & 1,270 \\
\hline 0.91 & 175 & 1,360 \\
\hline 0.96 & 200 & 1,723 \\
\hline
\end{tabular}

は回生インバータなどの採用により, 回生ブレーキにより 生じた電力を充電器もしくは架線に返すことなどで電力の より効率のよい再利用が期待することができ検討されてい る。

こういった次世代素子の使用には, ナノ $\mathrm{Ag}$ 焼結剂での 接合や，貴金属接合，直接接合などにより，実装工程およ び，信頼性の目途付けはある程度されてきている。

封止樹脂や接着剤なども, Tg（ガラス転移点温度）が $200^{\circ} \mathrm{C}$ 以上のものや，耐熱性が $300^{\circ} \mathrm{C}$ 程度あるものが開発 され，車載製品に要求される信頼性を担保できるレベルに あると認識している。

一方, 次世代素子の製品の材料はいずれも, コスト面で 大きな課題があり，いまだ大きな改善がみられない。そう いった状況が数年続いており, 従来技術をより限界設計 し，プリント配線板やはんだ接合を一工夫して，高温・長 寿命化にできないかという試みが具体的に検討され，製品 化もされつつある。

\subsection{PEA におけるはんだ材料, はんだ付け}

産業用の製品における, はんだ材料はより高温で使用さ れることが求められている。

一般的に高温クリープを考慮した金属材料設計では, T を使用材料， $\mathrm{Tm}$ を材料の融点とした場合， $\mathrm{T} / \mathrm{Tm}>0.5$ で 問題になり， $\mathrm{T} / \mathrm{Tm}$ が大きくなるほどクリープの問題は顕 著になると言われている。

はんだに関していうと表 1 に示すが，これまで一般的な プリント回路板は $60^{\circ} \mathrm{C}$ 程度の発熱温度で動作することを 想定している。この場合， T/Tm は 0.67 とクリープ変形が 顕著に進行し, その塑性変形による機械的強度変化をどの ように信頼性を得るかを実装技術者は工夫してきた。昨今, $100^{\circ} \mathrm{C}$ 動作保障や, $125^{\circ} \mathrm{C}, 150^{\circ} \mathrm{C}$ さらには $200^{\circ} \mathrm{C}$ など高温 化使用の開発も検討している。

イメージしやすい日本刀の焼き入れ温度が $750 \sim 800^{\circ} \mathrm{C}$ 程 度と言われ，鉄が赤くなった状態で鍛造する。はんだの $\mathrm{T} /$ $\mathrm{Tm}$ が 0.7 以上では, 融点に対してそれ以上の高温で使用す ることになり，材料強度の低下を伴うため，実装されたプ リント回路板のはんだ接合部や，パワーモジュールのはん だ接合部の高温動作化は，高温変形との挙動の制御技術の 開発が，日本の実装技術を優位にできるものと推測してい る。 
他方，一昨年とあまり状況は変わっていないが，一般的 な電子機器に用いられるはんだ材料は, 鉛フリー化がひと 段落し, 現在ではプリント回路板などの間材のコストダウ ンを行うために, $\mathrm{Ag}$ をより少なくする低 $\mathrm{Ag}$ 系 $\mathrm{SnAg}$ はん だや $\mathrm{SnCu}$ 系はんだが市場の $40 \%$ 程度を占めている。PEA 製品では, Sn-3.0Ag-0.5Cu はんだ材に扔いても，接合部の ボイド率が高く，亜共晶合金であるために，はんだ付け品 質が安定せず，製品の市場での課題を残している。これに は見かけ共晶凝固組織をより安定的に作れる成分や微量添

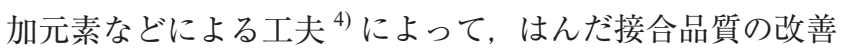
を要する。Made in Japan 製品の高い品質をもつ生産技術者 の努力が愚直に取り組まれており，応援もしたい。

現在では盛んに接合品質の安定化を製品の付加価值, メーカの高い信頼性と考える動きがあり, 真空リフロー炉 による接合中の接合欠陥の低減や, 酸化物を除去するため のフラックスに従来の臭素や塩素系とは別のフラックスに て，低ボイド化する技術が注目されて扔り活発化している。

特に高温になる製品群では, 従来の $\mathrm{SnAg}$ 系材料では, 十分な信頼性を確保することが困難であり, SnSb 合金の系 や $\mathrm{SnCu}$ 系などをべースに, 多元系材料が注目材料となっ ている。

\section{3 まとめ}

車両のリコールや, 製品の信頼性に関する話題が昨今多 く取り上げられている。直近の低コスト化, 事業化目標を 達成するためのその場逃れとも見受けられるメーカの姿勢 を耳にする機会も多くなり, 材料, 実装の研究や開発が消 極的になっているという印象がある。より高温で製品を動 作させるためには, 電子部品, めっき, 接合材料およびプ ロセスの再考が必須であり当研究会においても活発な議論 がなされている。ここ数年, 電子機器を購入すると当たり はずれがよくあるように思う。すぐ交換にしてくれるため 問題ないのだが，これもいろいろな面が合理化さている弊 害なのではないかと考えている。

大袈裟かもしれないが Made in Japan ブランドがなくなら ないためには, 今後もこういったPEA 技術についてもさら なる活発な研究と生産技術者が奮闘し, 開発されることに より, 安全で, 安定した品質の製品が上市されることを期 待している。

文責・渡邉裕彦 $/$ 富士電機

\section{4. 車載システムの動向と実装技術の課題}

最初に, パワートレインシステムの動向と実装技術につ いて述べる。ゼロエミッションに向けて自動車の動力が内 燃機関からモータへ移行しょうとしており, パワートレイ ンシステムの電動化が進んでいる。電動システムを構成す る機器としては, インバータ, DC-DC コンバータなどが あり, 実装技術においては, より大電流, 高放熱, 高絶 縁, 高耐熱が求められるようになってきている（図 4)。
次に, 走行安全制御の動向と実装技術について述べる。 自動運転車の開発が加速する中，それを支えるベース技術 の一つとして, 運転支援システム, 予防安全システムが進 化してきている。一例としてステアリングとブレーキを協 調制御することで車両の動きを安定に保つ技術が開発され ている。ステアリングを制御するEPS (Electric Power Steering) 㧍よびブレーキを制御する ESC (Electric Stability Control) がこのシステムを構成するメインの機器であり，

これらはモー夕と制御回路が一体化した構造となってい る。安全性を高めるために駆動回路を 2 系統設けた EPS が 開発されており，これまでのモータシルエット内に制御回 路とモー夕を収めるために, バスバー廃止による機電直接 接続，駆動回路圥長化での発熱分散によるヒートシンク小 型化などの実装構造の改良がなされている ${ }^{5)}$ 。この他，車 外センシング, 車室内制御の進化に伴い, 実装技術におい ては, 高周波対応, 大電流・高放熱化が求められる（図 5)。 情報通信システムの動向としては, 自動運転, および ADAS (Advanced Driver Assistance System) システムの構成 要素として, 周辺環境認識のためのセンシングやインフ ラ・社会と車，抢よび人と車をつなぐ(HMI: Human Machine Interface) 情報通信システムの開発が進んでいる ${ }^{6)}$ 。実装技 術においては，膨大な情報を高速に処理する高速伝送対 応，高放熱技術などが求められる（図 6)。

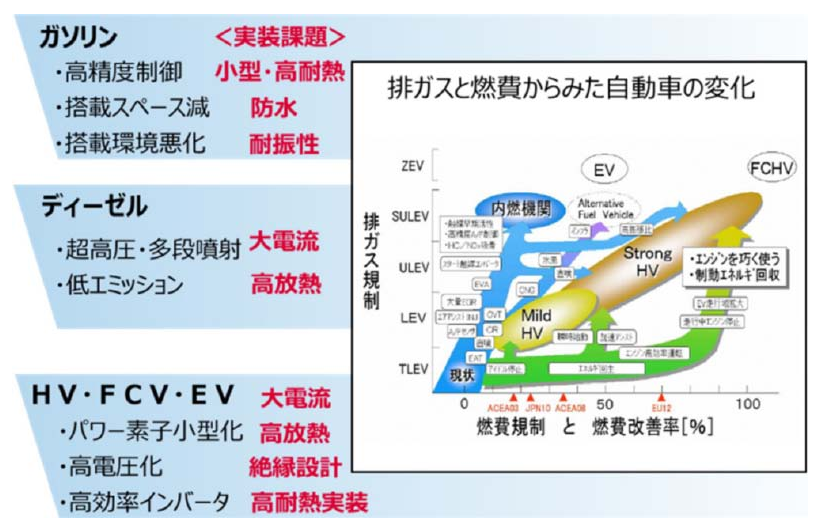

図 4.パワートレイン制御の動向と実装技術

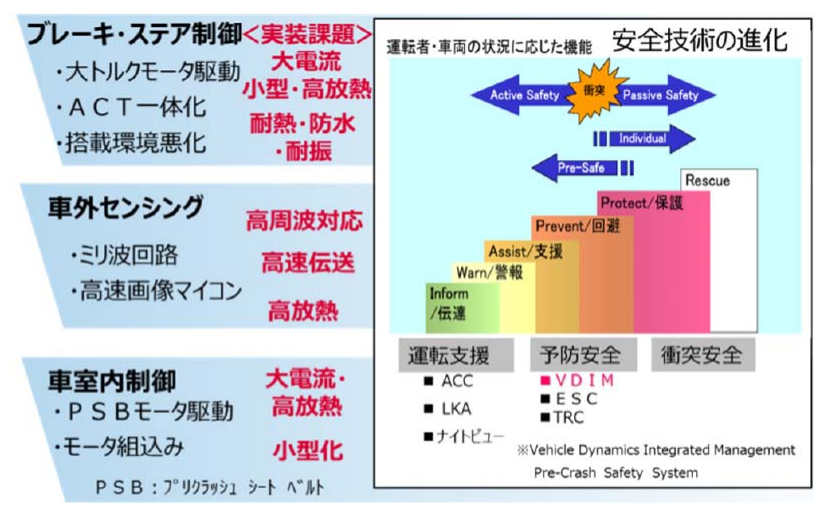

図 5. 走行安全制御の動向と実装技術 


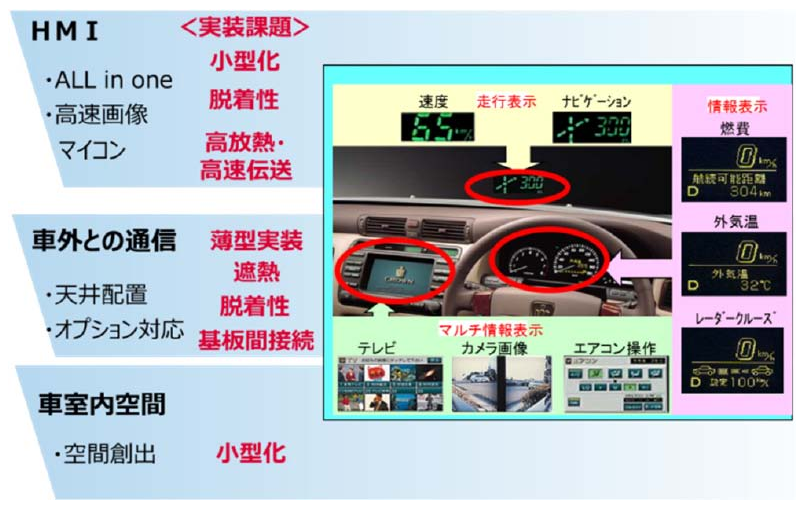

図 6. 情報通信システムの動向と実装技術

文責・三宅敏広／デンソー

\section{5. プリンタブルエレクトロニクス}

近年，印刷技術を用いてデバイスや配線板を形成するプ リンテッドエレクトロニクス技術が注目されている。印刷 技術はアディティブマニュファクチャリングであり，低コ ス卜化, 高生産性, 省資源化などを期待でき, 多品種少量 生産に向いていることから, さまざまな製品適用が試みら れている。しかし, これまでは, 短手番, 大面積などとい う製造・生産の視点からの印刷技術のメリットが挙げられ ており，「既存技術の代替」の要素が大半を占めていた。

これに対し，アディティブマニュファクチャリングのメ リットであるマスクレス, 短手番を活かしたプロトタイピ ングや研究開発では, 配線板の試作やへルスケア用途のセ ンシングなどに応用が広がっている。中でも, 印刷製造し た TFT アレイシート上に感圧層と感温層を持つ圧力・温度 センサー ${ }^{7)}$ が開発されており，フレキシブルで軽量なウエ アラブルセンサーとして期待されている。また, 多層化し た配線板を 3D 印刷で試作できる装置 ${ }^{8)}{ }^{8)}$ も開発され, PoC の実践などに効果的な技術となっている。

昨今では，モノとインターネットの融合により新たな付 加価值を創造する IoT (Internet of Things)の実用化に期待が 高まっている。ご存知の通り, ICT 機器のみならず, 自動 車, ロボット, 住宅設備などのあらゆるモノがインター ネットにつながり, 情報のデジタル化並びに知識化などが 進み, 新たな付加価值を生み出すものである。IoT の世界 を実現する上で，フロントエンドで適用される無線および センサー機能を搭載した IoT デバイスが市場をけん引して いくものと推測される。特に，センシングデバイスに大き
く係わっていく技術がプリンテッドエレクトロニクス技術 と考えられる。フレキシブル性を活かした RF-ID やビーコ ン ${ }^{10)}$ ，さらには MEMS センサーの製造などにも印刷技術 が応用されている。また，印刷配線上の部品実装におい て，はんだ接合に適さない $\mathrm{Ag}$ 電極がほとんどであったが, はんだ材料の代わりとして導電性接着剂 ${ }^{11)}$ が提案されてお り，モジュール化するための材料が揃ってきた。このよう に，印刷応用技術は日々進展しており，実用化を目指した 産官学の協力体制で，かつて日本の強みであったエレクト ロニクス分野の国際競争力を取り戻せることを期待する。

文責・阿部知行 $/$ 富士通

(2017.11.2- 受理)

\section{文献}

1) 戸田光昭：“車載エレクトロニクス実装の現状と展望,”エ レクトロニクス実装学会誌, Vol. 19, No. 1, p. 22, 2016

2) 戸田光昭：“電子部品と実装技術における現状および今後の 展望, ”エレクトロニクス実装学会誌, Vol. 16, No. 4, pp $265-269,2013$

3) 電子部品・実装技術委員会：“電子部品と実装技術における 現状および今後の展望, ”エレクトロニクス実装学会誌, Vol. 19, No. 1, p. 22, 2016

4) 渡邊裕彦 : “微量元素を添加した $\mathrm{SnAgCu}$ 系鉛フリーはんだ の産業電子機器への適用に関する開発,”エレクトロニクス 実装学会誌, Vol. 9, No. 6, pp. 1-8, 2016

5) 大橋正幸 : “EPS 用駆動 2 系統 MCU,” デンソーテクニカル レビュー, Vol. 21, pp. 48-49, 2016

6) 松ヶ谷和沖：“自動運転を支えるセンシング技術,”デン ソーテクニカルレビュー, Vol. 21,pp. 15-19, 2016

7) NEDO, JAPERA：プレスリリース“印刷技術で圧力と温度 を同時検出できるフレキシブルシートセンサーを世界で初 めて開発,”2017 年 2 月

8) 宇野麻由子：“プリンターで多層 $\mathrm{P}$ 板を作れる, リフローも 可能,”日経テクノロジー online, 2016 年 10 月

9) M. Fujita: "The 3D Inkjet Printing System for the 3D Micro Circuit Module Manufacturing," ICEP-IAAC 2015, pp. 334-340, 2015

10) 中本裕之：“変形自在で電池交換不要なフレキシブルビーコ ンを開発,”エレクトロニクス実装学会プリンタブルデバイ 又実装研究会公開研究会予稿集，2016 年 8 月

11）鵜飼育弘：“ウエアラブル EXPO 報告,”日経テクノロジー online, 2017 年 2 月 

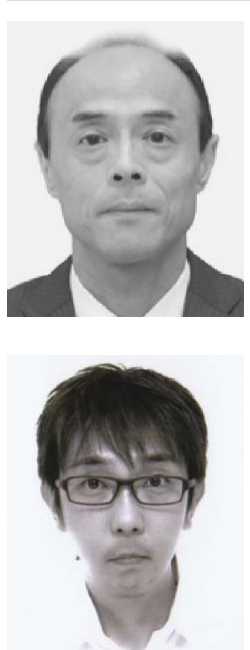

戸田光昭（とだ みつあき）

株式会社メイコー 執行役員 商品開発部 部長 1988 年日本ビクター株式会社に入社。VIL 基板開 発，デバイスの製造装置や成形金型の設計開 発，精密金属加工技術に従事。

2008 年株式会社メイコーへ事業譲渡により同社へ 転籍。部品内蔵配線板, 全層ビルドアップ構造 配線板，車載プリント配線板の開発掞よび生産 に従事。

渡邊裕彦（わたなべ ひろひこ）

1991 年駿台電子情報専門学校卒業。同年 4 月富士 電機株式会社生産技術研究所に入社。

2012 年群馬大学大学院工学研究科博士課程修了。 博士（工学）。国立東京高等専門学校 特別客 員教授。

現在，富士電機株式会社ものつくり戦略センター にて, はんだ材料開発, 接合, 信頼性プロセス の開発，生産技術者育成・教育に従事。

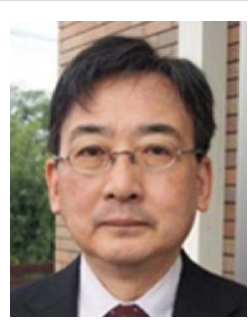

三宅敏広（みやけ としひろ）

1985 年岐阜大学大学院工学研究科修士課程修了, 1991 年株式会社デンソー入社, プリント配線板お よび接続技術開発に従事，2009年岐阜大学大学 院工学研究科博士後期課程物質工学専攻修了, 博士 (工学)。

現在，基盤ハードウェア開発部にて車載メカトロ ニクス実装技術開発に従事, JIEP 常任理事。

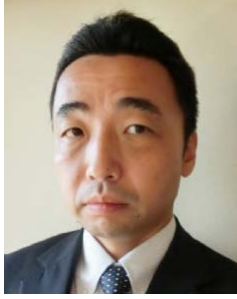

阿部知行（あべともゆき）

富士通株式会社 テクノロジ\&ものづくり事業本部 シニアマネージャー

1988 年 富士通株式会社 入社

同年 株式会社富十通研究所 入所

サーバ向け多層配線形成技術およびモバイル機器 向け実装技術の研究開発に従事。2016 年 5 月よ り現職。

現在，小型モジュールの実装技術掞よび量産技術 開発に従事。JIEP）電子部品・実装技術委員会 委員長。 